九州大学学術情報リポジトリ

Kyushu University Institutional Repository

Embryonic Development and Larvae of Genus Euiota (Pisces : Gobiidae) : I. Eviota abax and E. storthynx

Sunobe, Tomoki

Laboratory of Fisheries Biology, Faculty of Agriculture, Kyushu University

Nakazono, Akinobu

Laboratory of Fisheries Biology, Faculty of Agriculture, Kyushu University

https://doi.org/10.5109/23850

出版情報: 九州大学大学院農学研究院紀要. 31 (3), pp. 287-295, 1987-03-10. Kyushu University バージョン：

権利関係 : 


\title{
Embryonic Development and Larvae of Genus Eviota (Pisces : Gobiidae) \\ I. Eviota abax and E. storthynx
}

\section{Tomoki Sunobe and Akinobu Nakazono}

\author{
Laboratory of Fisheries Biology, Faculty of Agriculture, Kyushu University \\ 46-04, Hakozaki, Higashi-ku, Fukuoka 812, Japan
}

(Received September 24, 1986)

\begin{abstract}
Embryonic development and larvae of Eviotu abm and E. storthynx are described. Eggs are fusiform in both species, measuring 1.16-1.19 $\times 0.59-0.63 \mathrm{~mm}$ in E.abax and 1.19-1.31 x0.37$0.42 \mathrm{~mm}$ in E. storthynx. Numerous minute processes cover the surface of the eggs of both species, Total length of newly hatched larvae is $2.6-2.8 \mathrm{~mm}$ in $E$. $a b a x$ and $1.9-2.1 \mathrm{~mm}$ in $E$. storthynx. Cuplae and red pigments are observed in larvae of both species. Larvae of $E$. abax, reared for 16 days after hatching, grew to $4.3-4.5 \mathrm{~mm}$ in total length. In these larvae, as they grew, the number of melanophores decreased and the red pigments, which are marked features in the embryo, disappeared.
\end{abstract}

\section{INTRODUCTION}

Eviota abax and E. storthynx are small gobies that inhabit rocky reefs and coral reefs. Eviota abax is distributed in southern Japan (Yoshino and Shimada,1985a), and E. storthynx occurs northward to Kagoshima Prefecture, Japan and the western Pacific (Yoshino and Shimada, 1985b).

Embryonic development and larvae of Eviotu abax and E. storthynx were studied by Dotsu et al. (1965) and Shinomiya et al. (1981a) respectively. In this paper, we redescribe development of eggs and larvae of both species and discuss differences in morphological characteristics of embryos and larvae of these two species of Eviotu.

\section{MATERIALS AND METHODS}

The specimens of Eviota abax (one male, $28.5 \mathrm{~mm}$ in standard length (SL) and 3 females, 28.0, 26.2, $26.0 \mathrm{~mm}$ SL respectively) were collected by using a hand net at Kuchinoerabu Island, Kagoshima Prefecture, on 14 May 1985. Those of E. storthynx (one male, $26.0 \mathrm{~mm}$ SL and 2 females, 22.5, $21.7 \mathrm{~mm} \mathrm{SL}$ respectively) were collected by the same method at Sakurajima Island, Kagoshima Prefecture, on 31 July 1985.

They were brought to the laboratory and kept in a glass aquarium $(60 \times 30 \times 28$ $\mathrm{cm})$. Water was circulated and filtered through a layer of gravel at the bottom by a air-lift system. An opaque vinyl chloride pipe $(2 \mathrm{~cm}$ inside diameter and $5 \mathrm{~cm}$ long) was put on the bottom as a shelter for spawning and hiding. Minced fresh fish meat was fed once a day. 
Spawning of Eviota abax was observed on 25 and 28 May, and that of E. storthynx on 5, 10 and 17 August. Just after spawning, the opaque vinyl chloride pipe with an egg mass on its ceiling was placed in a plastic vessel $(15 \times 10 \times 8 \mathrm{~cm})$ fixed below the tap of air-lift pipe in the aquarium, so that filtered water ran over the eggs throughout development.

When the larvae hatched, 10 were put in each of several sealed $250 \mathrm{ml}$ glass bottles that were kept in the same aquarium. Half the water was changed daily. After the larvae had absorbed their yolk, rotifers and oyster larvae were put into the bottles. Water temperature, controlled with electric heaters, was kept between 24 and $27^{\circ} \mathrm{C}$ in both the aquarium and bottles.

Measurements were made through a binocular microscope (Nikon Model S) with a printer display calculater (Texas Instruments TI-5142). Drawings were made by the aid of a camera lucida.

Spawning took about 20-60 minutes in both species. The time when the spawning ended is regarded as that of fertilization.

\section{RESULTS}

\section{Embryonic development of Eviota abax}

Eggs are spawned in a single layer on the ceiling of the shelter. The number of eggs spawned by a female is $250-350$ per brood, and a male guards egg masses of one to three females at a time. The fusiform eggs, with a bundle of adherent threads at their base, measure 1.16-1.19 mm (mean $1.18 \mathrm{~mm}$ ) in length and 0.59-0.63 mm (mean $0.60 \mathrm{~mm})$ in breadth. Numerous minute processes cover the surface of the egg membrane (Fig. 1).

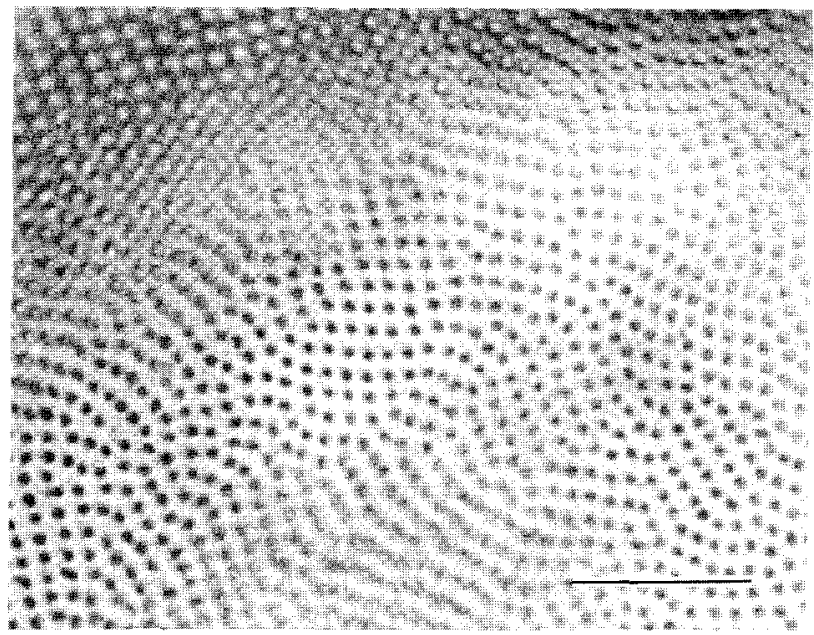

Fig. 1. Surface of the egg membrane of Eviotu abm. Scale indicates $20 \mathrm{pm}$ 

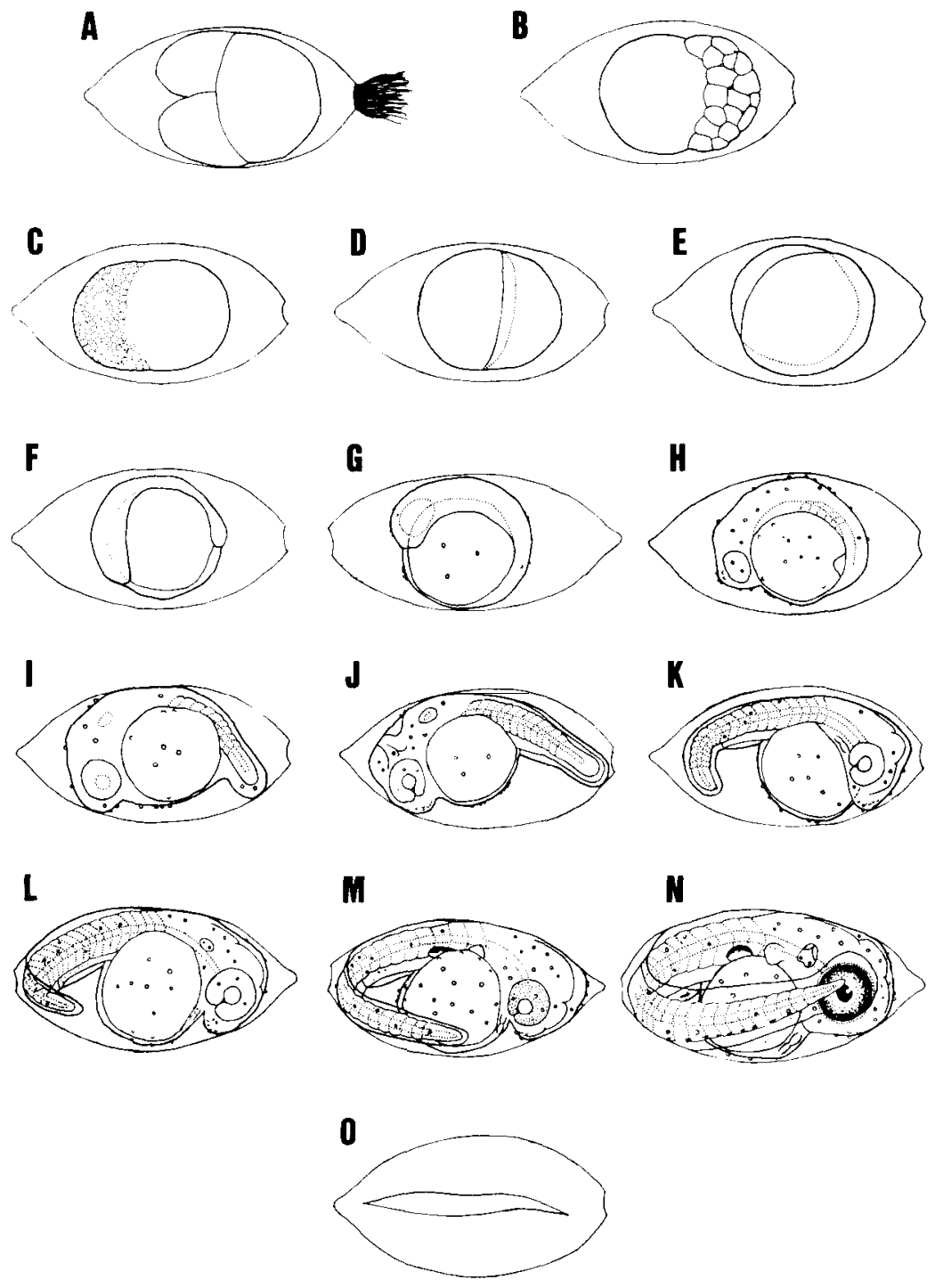

Fig. 2. Embryonic development of Eviota abax. A, $40 \mathrm{~min}$ after fertilization. B, $2 \mathrm{hr}$. $40 \mathrm{~min}$ after fertilization. C, $4 \mathrm{hr}$. after fertilization. D, $5 \mathrm{hr}$. after fertilization. E, 12 hr. after fertilization. F, 17hr. after fertilization. G, 19 hr. after fertilization. H, $21 \mathrm{hr}$. after fertilization. I, $29 \mathrm{hr}$. after fertilization. J, $34 \mathrm{hr}$. after fertilization. K, $42 \mathrm{hr}$. after fertilization. L, $48 \mathrm{hr}$. after fertilization. M, $62 \mathrm{hr}$. after fertilization. N, $80 \mathrm{hr}$. after fertilization. 0, Empty egg capsule with a hatching cleft. 
The first cleavage divides the blastodisc into two cells of equal size 40 min after fertilization (Fig. 2A). The 32-cells stage is achieved $1 \mathrm{hr} .40 \mathrm{~min}$ after fertilization (Fig. 2B), and the morula stage $4 \mathrm{hr}$. after fertilization (Fig. 2C). In the early gastrula stage, $5 \mathrm{hr}$. after fertilization (Fig. 2D), the blastodermal cup begins to spread over the surface of the yolk. By $12 \mathrm{hr}$. after fertilization (Fig. 2E), the rim of the germ ring covers about three-quarters of the yolk. Seventeen hr. after fertilization (Fig. 2F), the blastopore closes, and an embryonic body is formed. A pair of optic vesicles appears at $19 \mathrm{hr}$. (Fig. 2G), and granules are visible on the surface of the embryo. A Kupffer's vesicle appears and five pairs of myotomes can be recognized $21 \mathrm{hr}$. after fertilization (Fig. 2H). The number of the granules on the surface of the embryo increases.

Lenses are observed in the optic cup and a pair of ear vesicles appear at $29 \mathrm{hr}$. on the lateral sides of the nape (Fig. 21). A slight tail bud projects. The Kupffer's vesicle had disappeared. Nine pairs of myotomes are recognized, and the notochord is visible.

Brain differentiation is recognized and the tail become longer by $34 \mathrm{hr}$. (Fig. 2J).

Forty-two hr. after fertilization (Fig. 2K), a heart appears anterior to the yolk, the intestine is distinguished as a straight tube, and 18 pairs of myotomes are recognized.

The heart exhibits a rhythmical beat $48 \mathrm{hr}$. after fertilization (Fig. 2L). Two pairs of otoliths are recognized in the ear vesicles. Melanophores appear on the ventral part of the tail.

A gas bladder appears and pectoral fin buds are recognized $62 \mathrm{hr}$. after fertilization (Fig. 2M). Melanophores and red pigments appear on the gas bladder.

Red pigments appear on the anus and melanophores on the optic cups at $80 \mathrm{hr}$. (Fig. 2N). The tip of the looped tail reaches to the level of the eye.

Larvae hatch after sunset, $129 \mathrm{hr}$. after fertilization. An empty egg cupsule with a hatching cleft is shown in Fig. 20. The small oil globules in the yolk never merged to form larger ones.

\section{Larvae of Eviota abax}

The newly hatched larvae measure $2.6-2.8 \mathrm{~mm}$ in total length(TL)(Figs. 3A-1, A2 ), and have $9+16=25$ myotomes (adult $: 10+16=26$ ). The mouth has opened, although the yolk still remains. Peristalsis of the digestive tract can be seen. The larvae show positive phototaxis. Eight pairs of cuplae and free neuromasts are observed (Fig. 3A-2). The cuplae easily fall off after fixation with $5 \%$ formalin. Four to eight small dendritic melanophores are observed on the ventral part of the tail. Others are recognized on the optic cups, the dorsal surface of the gas bladder and the dorsal part of the rectum. Red pigments are on the dorsal surface of the gas bladder, the anus, ventral part of the abdomen, and the tail region.

One day after hatching, when the larvae are 2.9-3.0 mm TL (Fig. 3B), the yolk has been absorbed, and a few rotifers are recognized in the digestive tract.

The myotomes attain the same number as adult $(10+16)$ seven days after hatching, when the larvae are 3.4-3.6 mm TL (Fig. 3C). The melanophores and the red pigments decrease in number. However, a melanophore newly appears on the otolith. The cuplae and the free neuromasts disappear. Primordiums of hypurals and caudal fin rays appear.

Fifteen days after hatching, at 4.3-4.5 mm TL (Fig. 3D), the end of the notochord 

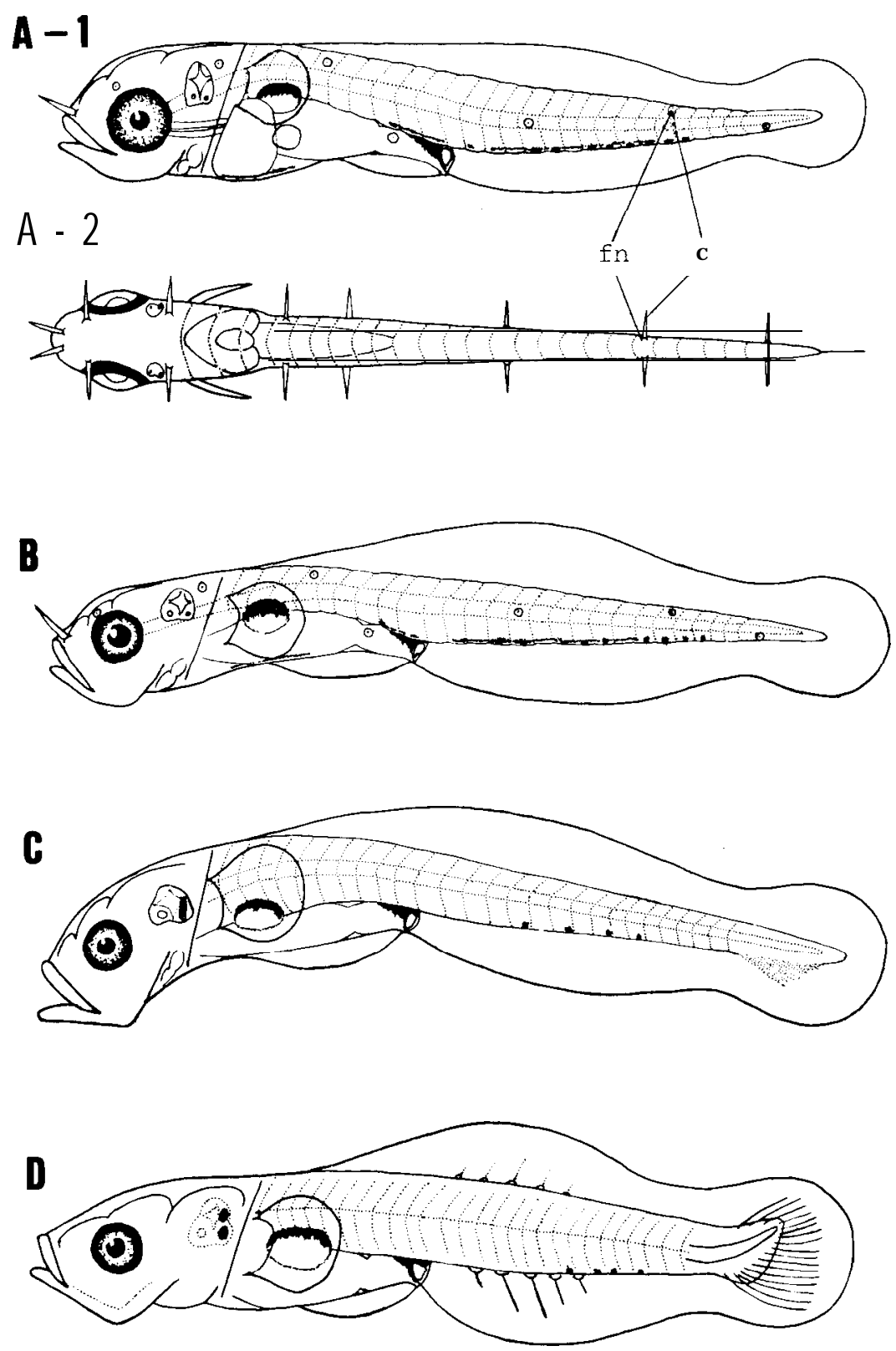

Fig. 3. Larvae of Eviota abax. A-1, newly hatched larvae, $2.62 \mathrm{~mm}$ in total length (TL). A-2, Dorsal view of the same specimen. B, 1 day old after hatching, $2.90 \mathrm{~mm}$ TL. C, 7 days after hatching, $3.55 \mathrm{~mm}$ TL. D, 15 days after hatching, $4.36 \mathrm{~mm}$ TL. c, cupla; $\mathrm{fn}$, free neuromast. 
bends upward and urostyle is formed; buds of dorsal and anal fins disappear; a melanophore on the otolith is divided into two ; the red pigments disappear.

By the 17th day after hatching, all the larvae had died.

\section{Embryonic development and larvae of Eviota storthynx}

We will breafly describe embryonic development and larvae of $E$. storthynx, as Shinomiya et al. (1981a) reported it in detail.

Eggs are spawned in a single layer on the ceiling of the shelter. They are fusiform with a bundle of adherent threads at their base, measuring 1.19-1.31 mm (mean 1.24 $\mathrm{mm}$ ) in length and $0.37-0.42 \mathrm{~mm}$ (mean $0.40 \mathrm{~mm}$ ) in breadth, and have numerous minute processes and large ones of irregular size scattered all over the egg membrane (Fig. 4). The number of eggs spawned by a female is 200-250 per brood.

The 2-cells stage is achieved $30 \mathrm{~min}$ after fertilization (Fig. 5A), and the morula stage 4 hr. after fertilization (Fig. 5B).

Eighteen hr. after fertilization (Fig. 5C), a Kupffer's vesicle appears three pairs of myotomes are recognized. Some granules are observed on the surface of the embryo.

Lenses are observed in the optic cups and a pair of ear vesicles appears on the lateral sides of the nape at $33 \mathrm{hr}$. (Fig. 5D). The slight tail bud projects. The Kupffer's vesicle had disappeared. Seven pairs of myotomes are recognized. The notochord is visible.

Pectoral fin buds are recognized, and melanophoes appear on the optic cups $70 \mathrm{hr}$. after fertilization (Fig. 5E).

Larvae hatch after sunset, $110 \mathrm{hr}$. after fertilization. An empty egg capsule with a hatching cleft is shown in Fig. 5F. The small oil globules in the yolk did not merge to form larger ones throughout development.

The newly hatched larvae measure 1.9-2.1 mm TL (Figs. 5G-1, G-2), and have $8+$

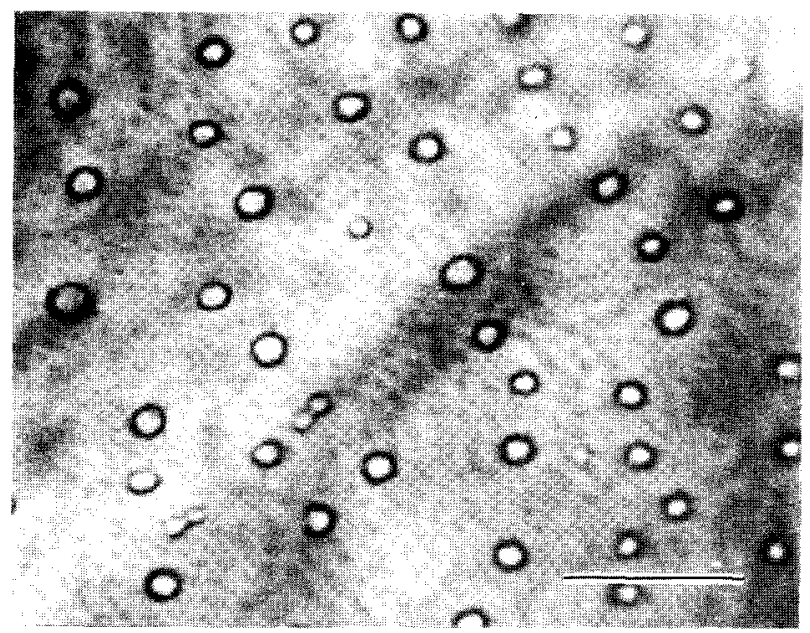

Fig. 4. Surface of the egg membrane of Eviota storthynx. Scale indicates $20 \mu \mathrm{m}$. 
A

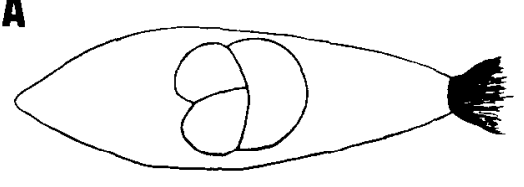

C

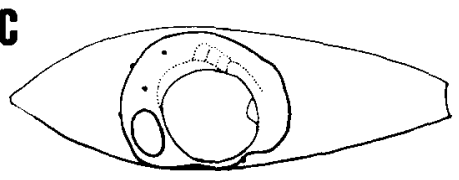

E

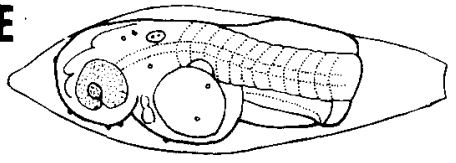

B

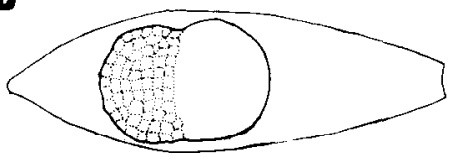

D
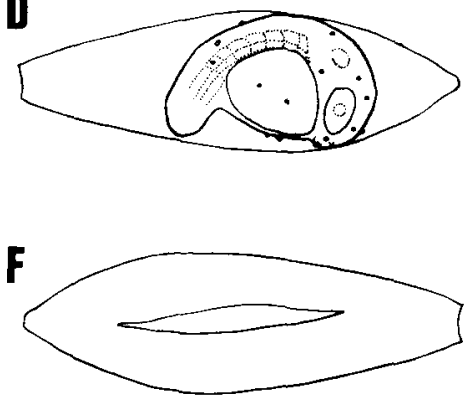

\section{G I}

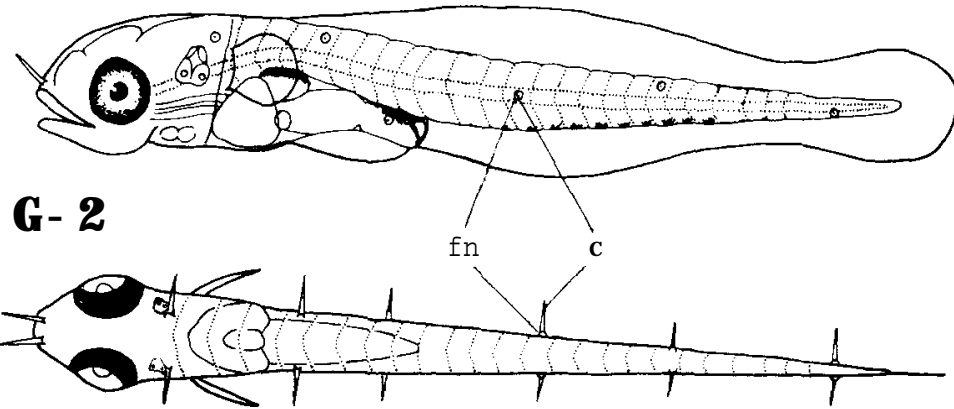

H

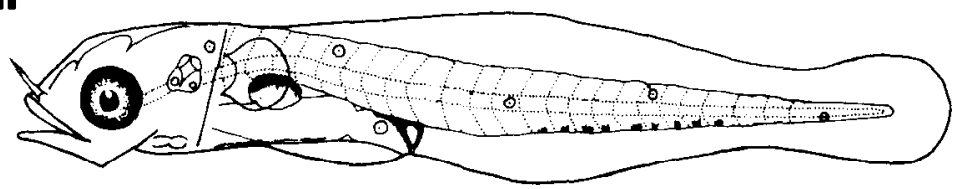


$15=23$ myotomes (adult: $10+15=25$ ). The yolk sac still remaines, but the mouth had opened and peristalsis of the digeastive tract can be seen. The larvae show positive phototaxis. Seven pairs of cuplae and free neuromasts are observed (Fig. 5G-2). The cuplae easily fall off when the animal is fixed with $5 \%$ formalin. Eight to twelve small dendritic melanophores are observed on ventral part of the tail. Others are recognized on the optic cups, the dorsal surface of the gas bladder, and the dorsal part of the rectum. Red pigments are on the dorsal surface of the gas bladder and the ventral part of the abdomen.

One day after hatching, the larvae measure 2.0-2.2 $\mathrm{mm}$ in TL (Fig. 5H), the yolk has been absorbed, but no food is recognized in the digestive tract. All larvae had died of starvation by the 4th day after hatching.

\section{DISCUSSION}

Dotsu et al. (1965) reported that diameter of eggs and total length of newly hatched larvae of Eviota abax were 2.3-2.5 x 1.0-1.1 mm and 4.4-4.5 mm, respectively at Tsuyazaki, Fukuoka Prefecture. This is nearly twice as large as those of the present results. On the other hand, those from Nagashima, Kagoshima Prefecture, are 1.4$1.5 \times 0.7-0.9 \mathrm{~mm}$ and $3.1-3.3 \mathrm{~mm}$ (Sunobe, unpublished). It seemes to be intraspecific variations of egg diameter and total length of newly hatched larvae of $E$. abax.

It is known that small oil globules in the yolk merge to large ones through egg development in the most of gobiid fishes (Tanaka et al., 1982). However, those of Eviota abax and E. storthynx did not merge. The few other gobiid species with the same character are as follows : Bathygobius fuscus (Gobius poecilichthys in original paper), Parioglossus dotui (taeniatus), Silhouettea (Ctenogobius) dotui, Odontobutis obscura obscura (Mogurnda obscura), Periophthalmus cantonensis, Gobiosoma oceanops, Acentrogobius pflaumi, Favonigobius (Acentrogobius) gymnauchen, Parioglossus formosus (taeniatus) and Valenciennea (Eleotriodes) helsdingeni (Dotsu, 1955 ; Dotsu, 1956 ; Dotsu, 1958; Dotsu and Tsukahara, 1964 ; Kobayashi et al., 1972 ; Valenti, 1972 ; Uchida and Dotsu, 1980 ; Uchida and Dotsu, 1980 ; Shinomiya et al., 1981b; Tanaka et al., 1982).

Dotsu et al. (1965) and Shinomiya et al. (1981a) did not recognize any Kupffer's vesicle in Eviota abax and $E$. storthynx. However, the present study revealed the existence of the Kupffer's vesicle as is usual in other gobiid fishes. Morphological characteristics of eggs and embryonic development of E. abax and E. storthynx include numerous minute processes on the surface of the egg membrane, granules on the surface of the embryo, and unmerged oil globules. Larvae of both species have red pigments, which is rarely known in other gobiid fishes except for Acanthogobius lactipes (Uchida and Dotsu, 1980). Further comparative study is needed to determine whether these characteristics are specific to the present species or not.

Larvae of Eviota abax and E. storthynx resemble each other in the distribution of melanophores (Figs. 3A-1;5G-1). Total length of larvae can be used to distinguish $E$. abax from $E$. storthynx. 


\section{ACKNOWLEDGEMENTS}

We are indebted to Dr. Daphne G. Fautin, Department of Invertebrate Zoology, California Academy of Sciences and Dr. Takeo Okuda, Laboratory of Fisheries Biology, Faculty of Agriculture, Kyushu University for their kind review of the manuscript. We thank Dr. Akihiko Shinomiya, Laboratory of Marine Biology, Faculty of Fisheries, Kagoshima University and Dr. Tatsuo Hamano, Department of Fisheries, Faculty of Agriculture, Kyushu University for their valuable advice. Thanks are also due to Dr. Yasuo Yone, Fishery Research Laboratory, Kyushu University for his kind cooperation throughout this study.

This work was supported in part by a Grant-Aid for Special Project Research on Biological Aspects of Optimal Strategy and Social Structure from the Japan Ministry of Education, Science and Culture.

\section{REFFERENCES}

Dotsu, Y. 1955 Life history of a goby, Gobius poecilichthys Jordan et Snyder. Sci. Bull. Fac. Agr., Kyushu Univ., 15 : 77-86 (in Japanese with English summary)

Dotsu, Y. 1956 The life history of an eleotrid goby, Parioglossus taeniatus Regan. Sci. Bull. Fac. Agr., Kyushu Univ., 15 : 489-496 (in Japanese with English summary)

Dotsu, Y. 1958 The bionomics and life history of the gobioid fish, Ctenogobius dotui Takagi. Sci. Bull. Fac. Agr., Kyushu Univ., 16:427-432 (in Japanese with English summary)

Dotsu, Y., I. Arima and S. Mito 1965 The biology of the eleotrid fishes, Eviotu abax and Eviota zonura. Bull. Fac. Fish., Nagasaki Univ., (18) : 41-50 (in Japanese with English summary)

Dotsu, Y. and H. Tsukahara 1964 The life history of the eleotrid fish, Mogurndaobscura Temminck et Schlegel. Bull. Japan Soc. Sci. Fish., 30: 335-342 (in Japanese with English summary)

Kobayashi, T., Y. Dotsu and N. Miura 1972 Egg development and rearing experiments of larvae of the mud skipper, Periophthalmus cantonensis. Bull. Fac. Fish., Nagasaki Univ., (33): $49-62$ (in Japanese with English summary)

Shinomiya, A., K. Maeyama and S. Imai 1981a Reproductive behavior of the goby Eviota storthynx (Rofen). Mem.Fac. Fish., Kugoshima Univ., $30: 237-246$ (in Japanese with English summary)

Shinomiya, A., K. Maeyama and S. Imai 1981b Reproductive behavior of the goby Parioglossus taeniatus (Regan). Mem. Fac. Fish., Kagoshima Univ., 30: 247-255 (in Japanese with English summary)

Tanaka, Y., K. Suzuki and A. Doi 1982 Reproduction and early life history of the gobioid fish, Eleotriodes helsdingeni Bleeker. J.Fac. Mar. Sci. Tech., Tokai Univ., (15) : 367-376 (in Japanese with English summary)

Uchida, T. and Y. Dotsu 1980 Larvae and juveniles of three Japanese common gobiid fishes reared in vessels, Bull. Fac. Fish., Nagasaki Univ., (49) : 25-33 (in Japanese with English summary)

Valenti, R. J. 1972 The embryology of the neon goby, Gobiosoma oceanops. Copeia, 1972 : 477-482

Yoshino, T. and K. Shimada 1985a Eviota abax.In "The Fishes of the Japanese Archipelago", ed. by H. Masuda, K. Amaoka, C. Araga, T. Uyeno and T. Yoshino, Tokai Univ. Press, Tokyo, p. 243

Yoshino, T. and K. Shimada 1985b Eviota storthynx.In "The Fishes of the Japanese Archipelago", ed. by H. Masuda, K. Amaoka, C. Araga, T. Uyeno and T. Yoshino, Tokai Univ. Press, Tokyo, p. 244 